\title{
The Development and Prospect of Indonesian Palm Oil Industry and Its Derivative Products
}

\author{
Nila Rifai ${ }^{1}$, Yusman Syaukat ${ }^{2}$, Hermanto Siregar ${ }^{2}$, E. Gumbira Sa'id ${ }^{3}$ \\ ${ }^{\prime}$ (Departement of Agricultural Economics , Bogor Agricultural University, Indonesia) \\ ${ }^{2}$ (Departement of Economics, Bogor Agricultural University, Indonesia) \\ ${ }^{3}$ (Departement of Agricultural Industry Technology, Bogor Agricultural University, Indonesia)
}

\begin{abstract}
In 2013, the world palm oil production reached 55.7 million tons. Indonesia and Malaysia shared $85 \%$ of it with their production of 26.70 and 21.70 million tons, respectively. The aims of this study were to identify and analyze the development and prospect of Indonesian palm oil industry and its derivative products. Data were analyzed by using a descriptive approach. The area of oil palm plantation increased to 9,074,621 ha in 2012. Indonesia's palm oil production in 2012 was 23.5 million tons. There was also an increased Indonesia's palm oil export to 18.15 million tons in 2012. In 2010, the installed capacity of cooking oil industry in Indonesia was 15.4 million tons. For fatty alcohol industry, the installed capacity was 320,000 tons/year. In 2007, with real production of 300,000 tons, the 100\% real capacity was almost reached. The installed capacities of biodiesel and glycerin industries in 2011 were 3.4 million kiloliters/year and 142,700 ton/year, respectively. In 2010, glycerin production was about 204,394 tons. Glycerin production was 121,640 kiloliters from fatty acid and fatty alcohol industries and 61,694 kiloliters from biodiesel industry.
\end{abstract}

Key words: oil palm, downstream oil palm industry, export, import.

\section{Introduction}

The world demand for plant oil is increasing. In 2013, the world demand for this oil was 162.8 million tons and was projected to reach 315.2 million tons in 2030 as a result of the world population growth and the shift in demand from fossil fuel to biofuel (Indonesian Palm Oil Board, 2014). Today, the fulfillment of global need of biofuel comes from palm oil (36.1\%), soybean oil (27.4\%), rapeseed oil (15.2\%), and the other nine kinds of biofuel $(21.4 \%)$.

In 2013, the world palm oil production was 55.7 million tons. Indonesia and Malaysia shared $85 \%$ of it with their production of 26.70 and 21.70 million tons, respectively (Fig. 1). In the same year, Indonesia had the export volume of palm oil and its derivative products of 21.2 million tons with a value of US $\$ 19.1$ billion (47\% of international palm oil trade) while Malaysia had 19.8 million tons ( $44 \%$ of international palm oil trade) (Indonesian Palm Oil Board, 2014).

As the world biggest palm oil producer, the export share of Indonesian palm oil and its derivative products is less competitive than that of Malaysia. Of the total national crude palm oil (CPO) production in 2013, only 4 million tons was consumed as cooking oil, 7.7 million tons was used for oleochemicals and biodiesel, and the remaining was exported in the form of CPO. On the other hand, Malaysia exported more oil palm derivative products with higher added values. According to Malaysian Palm Oil Board (MPOB), in 2013, Malaysia exported only 3,8 million tons of $\mathrm{CPO}$ and 17.9 million tons of CPO derivatives produced by refinery industries. This condition was very different from that of Indonesia with $40.34 \%$ export was in the form of CPO and only $59.38 \%$ in the form of downstream products.

With the production target of 40 million tons in 2020 , it is necessary that Indonesia develop its palm oil downstream industries, improve its export, and create new markets for its palm oil and palm oil derivatives in order to avoid excess supply of palm oil. The development of palm oil downstream industry plays a significant role in the national economy, especially as foreign currency generator which can contribute to national GDP by $4.5 \%$, provide employment for about 3.3 million families or 13.2 million people (SBRC, 2011). In the future, the need for food, feed, and fuel is increasing which, consequently, will make the need for raw materials to produce them increase and oil palm has big potential to provide those materials.

The aims of this study were to identify and analyze the development and prospect of Indonesian palm oil industry and its derivative products. Results of this study were expected to provide bases for making strategic plans in the development of Indonesian palm oil industry and its derivative products. 


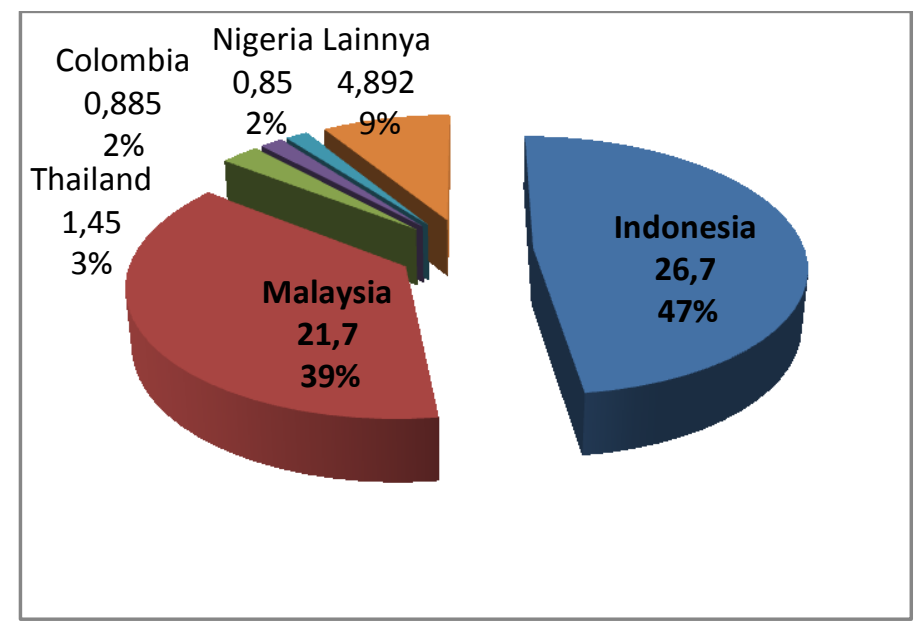

Source: Indonesian Palm Oil Board, 2014

Figure 1. World palm oil production (million tons) according to countries in 2013

\section{Research Methodology}

Primary and secondary data were used. Primary data were obtained from surveys, expert interviews, and focus group discussion (FGD). Secondary data were obtained from Ministry of Industry, Ministry of Agriculture, Ministry of Trade, Statistics Indonesia (BPS), Ministry of Finance, Bank of Indonesia, Indonesian Palm Oil Association, and other related institutions and associations. A descriptive approach was used in data analysis.

\section{Results And Discussion}

\subsection{Analysis of the Development of Indonesian Palm Oil Industry and Its Derivative Products}

As a superior plantation product, oil palm in Indonesia is experiencing increased production every year. This increasing production is the result of the expanding oil palm plantation areas. In 1988, oil palm plantation area was only 862,590 hectares. However, in 2012, the area increased to 9,074,621 hectares as seen in Fig. 2. Oil palm plantation in Indonesia is owned by individuals (43.7\%), state companies $(8.4 \%)$, and private companies (47.8\%) (Ministry of Agriculture, 2013). As the plantation areas are increasing, there is also an increased production of fresh fruit bunches and palm oil as seen in Fig. 3. In 1988, palm oil production was 1.71 million tons which increased 13 fold within the last 24 years into 23.5 tons in 2012 . For palm oil export, there was also an increase to 187.15 million tons in 2012, an increase of up to 20 times of the export volume in 1988 as seen in Fig. 4.

As one of the palm oil derivative industries, cooking oil/refinery industry of oil palm is the biggest consumer of CPO. Cooking oil industries on average absorb about $80 \%$ of total national CPO consumption. Data of Ministry of Trade in 2010 showed that the installed capacity of Indonesia's cooking oil industry was 15.4 million tons. These cooking oil industries spread out in 13 provinces all over the country. The largest areas of cooking oil plants was found in Sumatra, followed by those in Java, Sulawesi, and Kalimantan. Five provinces with the largest areas include North Sumatra (30.46\%), Riau (24.83\%), DKI Jakarta (13.01\%), East Java (9.62\%), and South Sumatra (7.18\%). It was found that cooking oil industries were not only distributed in locations of production center but also in consumption centers in Java. Production distribution in consumption centers was related to the status of cooking oil as a consumer good. Cooking oil production in Indonesia was found to increase by, on average, $10.6 \%$ per year with a production of 10.20 million tons in 2010 . This increase was in line with the improving demand as a result of increased income and population growth in Indonesia. 


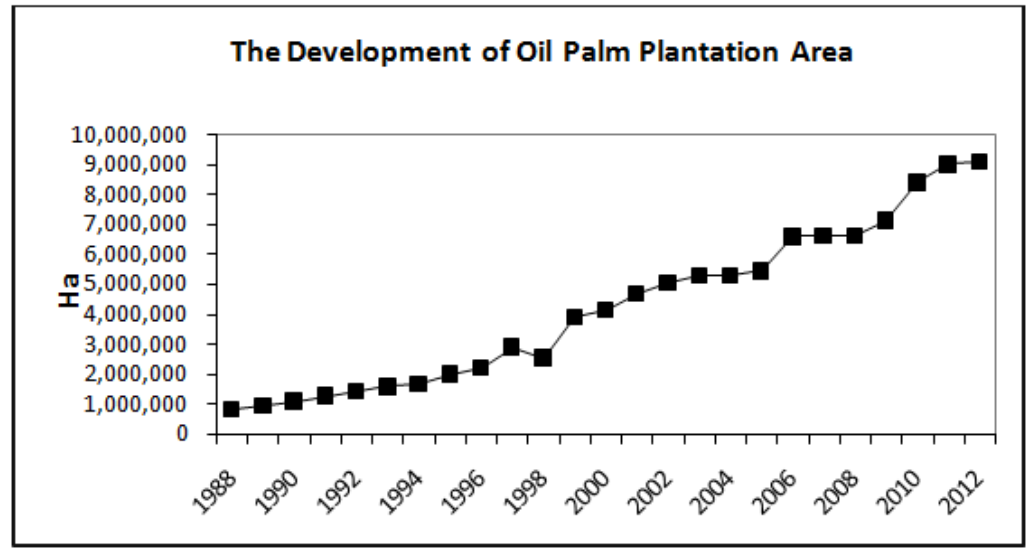

Source : Ministry of Agriculture (2013)

Figure 2. The Development of Oil Palm Plantation Area

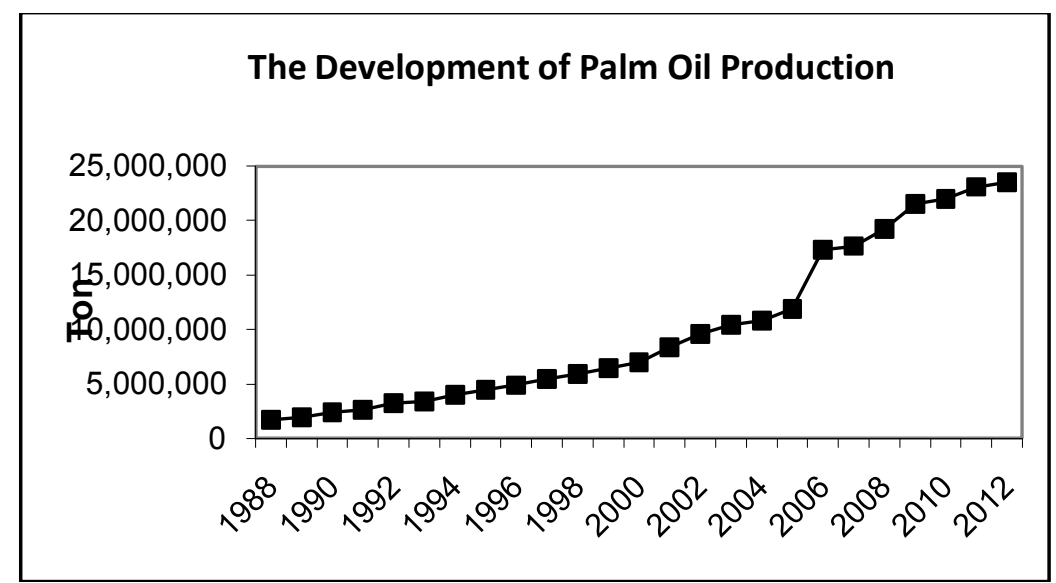

Source : Ministry of Industry (2013)

Figure 3. The Development of Palm Oil Production

For fatty acid, in 2011, there were nine fatty acid industries in Medan, Kuala Tanjung, Batam, Tangerang, Rantau Prapat, Bekasi, and Gresik. The installed capacity of these industries in 2011 was 996 thousand tons. Fatty acid production in 2007 was 754,180 tons or about $90 \%$ of the actual capacity. Overall, there was a fluctuated growth of fatty acid production but there was an improving trend by, on average, $9.41 \%$ per year.

For fatty alcohol, there were three fatty alcohol industries in Indonesia in 2011 located in North Sumatra Province. The total installed capacity was 320,000 tons/year. The real capacity was nearly $100 \%$ as in 2007 the real production reached 300,000 tons.

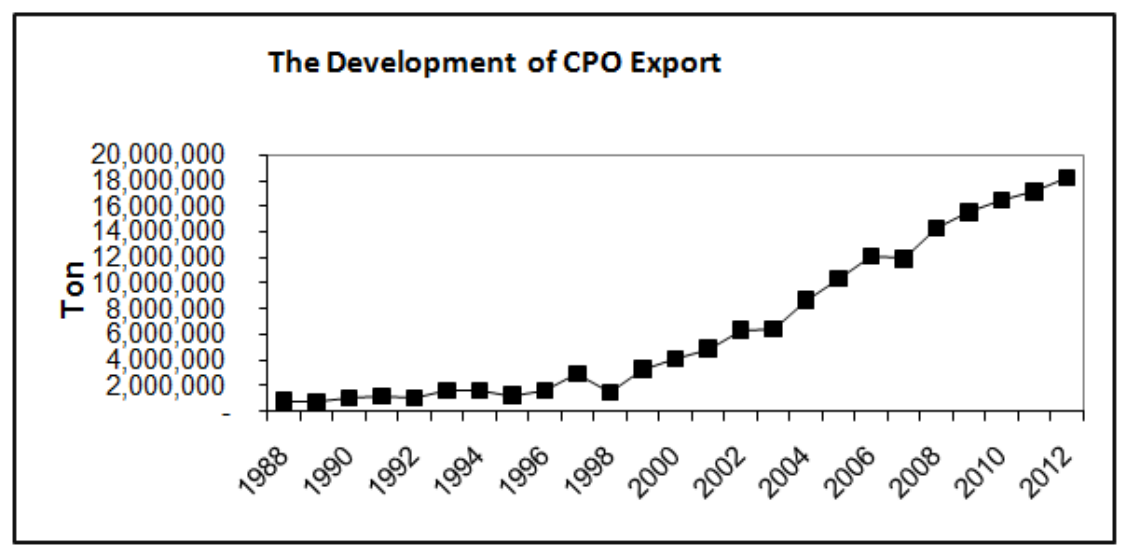

Source : Ministry of Industry (2013)

Figure 4. The Development of Palm Oil Export 
Biodiesel is bioenergy or biofuel made of plant oil through transesterification, esterification, or esterification-transesterification processes. In 2011, there were 24 biodiesel producers in Indonesia with an installed capacity of 3.4 million kiloliters per year. Of total biodiesel production, PT Wilmar Bioenergy had the biggest installed capacity of 1.6 million kiloliters followed by PT Musim Mas with 420 thousand kiloliters, and PT Cemerlang Energi Perkasa with 400 thousand kiloliters. Today, marketing seems to be the main problem found in the development of domestic biodiesel industry. This is caused by the high price of CPO and lower price of fossil fuel in global market making biodiesel industries unable to compete with petrodiesel. Biodiesel production in Indonesia is still under capacity. According to APROBI, in 2010, biodiesel industries in Indonesia produced about 688,288 tons which was only about $20 \%$ of their installed capacity. With highly potential feedstock and technology it has, Indonesia can have higher production. However, in domestic market, Indonesian biodiesel products fail to compete with petrodiesel, their substitute product.

Glycerin is a byproduct of fatty acid, fatty alcohol, and biodiesel processing industries. These processing industries produce about $10 \%$ crude glycerin. This crude glycerin is purified for a higher added value. The installed capacity of glycerin industry in Indonesia in 2011 was 142,700 tons/year. In 2010, the glycerin production was 204,394 tons. Fatty acid and fatty alcohol industries produced 121,640 kiloliters of glycerin and biodiesel industry produced 61,694 kiloliters.

\subsection{Export-Import Development of Palm Oil Derivatives Industry}

In the period of 2006 to 2100, export of RBD olein increased by, on average, $10.7 \%$ year. This significantly high export volume and increment indicated a significant overseas market opportunity. The development of Indonesian RBD olein export in 2006-2010 is given in Fig. $\mathbf{5}$.

RBD stearin is a raw material for margarine, shortening, CBS, vegetable ghee, and other food products. The export volume of stearin was significantly high and reached 1.4 million tons in 2010. This high export volume of stearin indicated a significant overseas market opportunity. Although in 2006-2010 the export of RBD stearin fluctuated, there was a tendency to increase by, on average, $3.34 \%$ per year. The development of Indonesian RBD stearin export in 2006-2010 is given in Fig. 6.

Indonesia is a fatty acid exporting country. The development of Indonesian fatty acid export and import is depicted in Fig. 7. During the period of 2003 to 2010, the export of fatty acid increased by $15.23 \%$ per year. This fatty acid is exported to Asian region including Japan, Hongkong, Korea, Taiwan, China, Thailand, and India. The export destinations in African region include Kenya, Sudan, Tanzania, Tunisia, and Morocco, in European region include the Netherlands, Germany, Spain, and Sweden, and in American region include Mexico, Brazil, and Canada. Fatty acid export behavior is influenced by feedstock price and fatty acid production behavior.

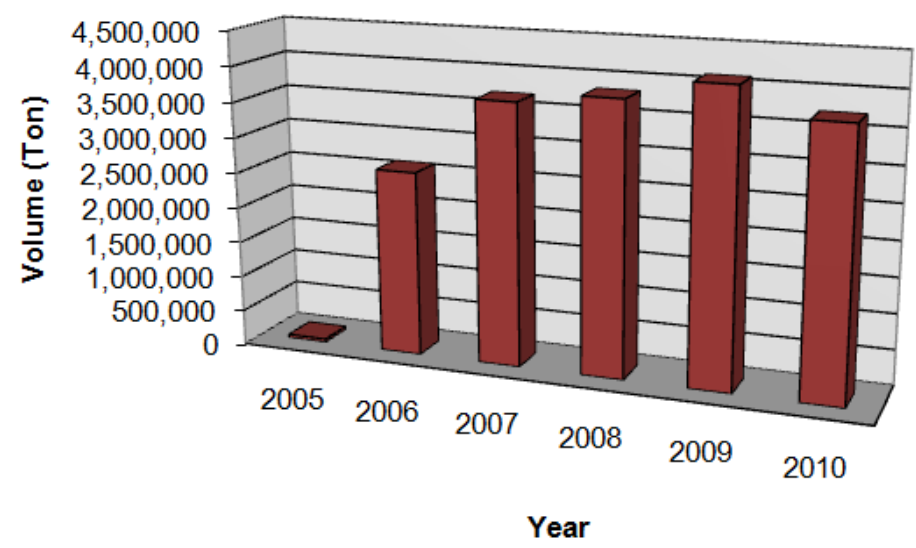

Source: Ministry of Industry, 2011

Figure 5. The Export Development of Indonesian Olein in $2005-2010$ 


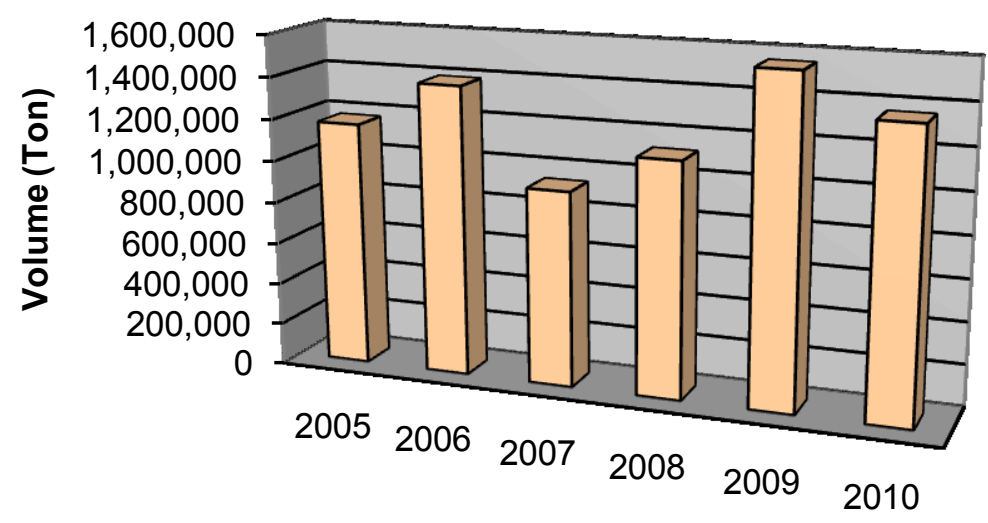

Year

Source: Ministry of Industry, 2011

Figure 6. The Export Development of Indonesian Stearin in $2005-2010$

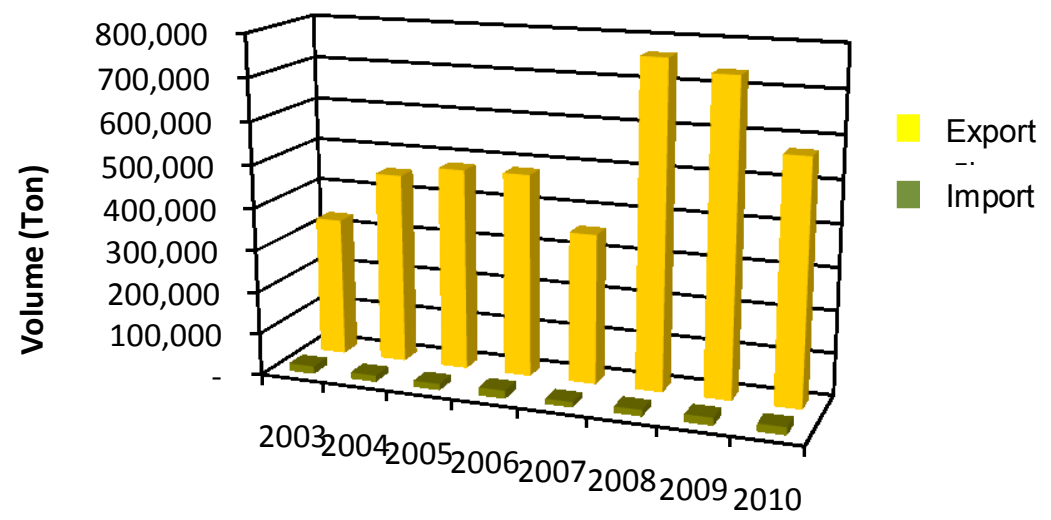

Source : Ministry of Industry, 2011

Figure 7. The Development of Export and Import of Indonesian Fatty Acid in 2003-2010

Although there have been fatty acid producers in Indonesia, import of fatty acid is still found. It is suspected that this import is done to cater for the domestic need of tallow base fatty acids. These fatty acids are different from Indonesian ones made of PKO and palm stearin and are used to obtain a certain quality in final products.

Most Indonesian fatty alcohol is exported to other countries. During the period of 2003 to 2010, export of Indonesian fatty alcohol improved by $14.3 \%$ per year. However, fatty alcohol import is still high. From 2003 to 2010, fatty alcohol import improved significantly by $11.9 \%$ per year as seen in Fig. 8. Indonesian fatty alcohol export destinations include Japan, India, Singapore, Korea, China, the Netherlands, Germany, USA, and Brazil.

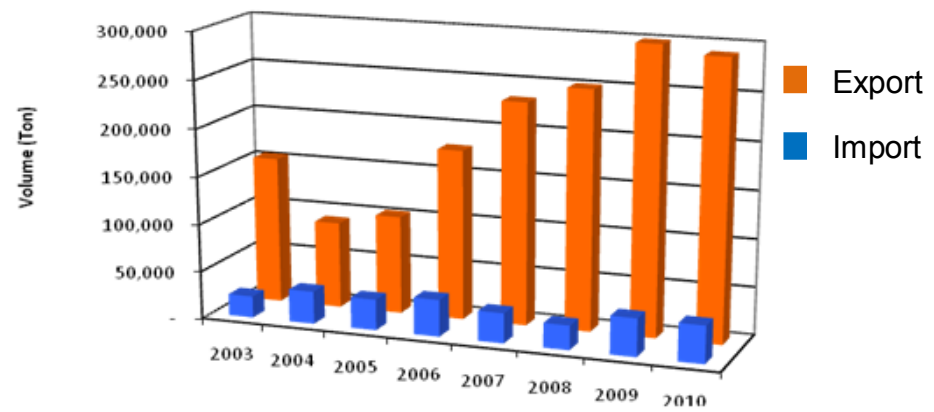

Source : Ministry of Industry, 2011

Figure 8. The Development of Export and Import of Indonesian Fatty Alcohol in 2003-2010 
From 2007 to 2010, the development of Indonesian biodiesel export was significantly high and, on average, reached $166.8 \%$. In contrast, in the same period, Indonesian import of biodiesel decreased steadily by the rate of $10 \%$ per year as seen in Fig. 9. Indonesian biodiesel is exported to Germany, the Netherlands, USA, Japan, and Singapore.

During 2003 to 2010, glycerin export improved by 35.5\% per year as depicted in Fig. 10. Indonesian glycerol exporting destinations include Japan, Hongkong, Korea, China, Thailand, India, North Africa, USA, the Netherlands, Germany, and Spain.

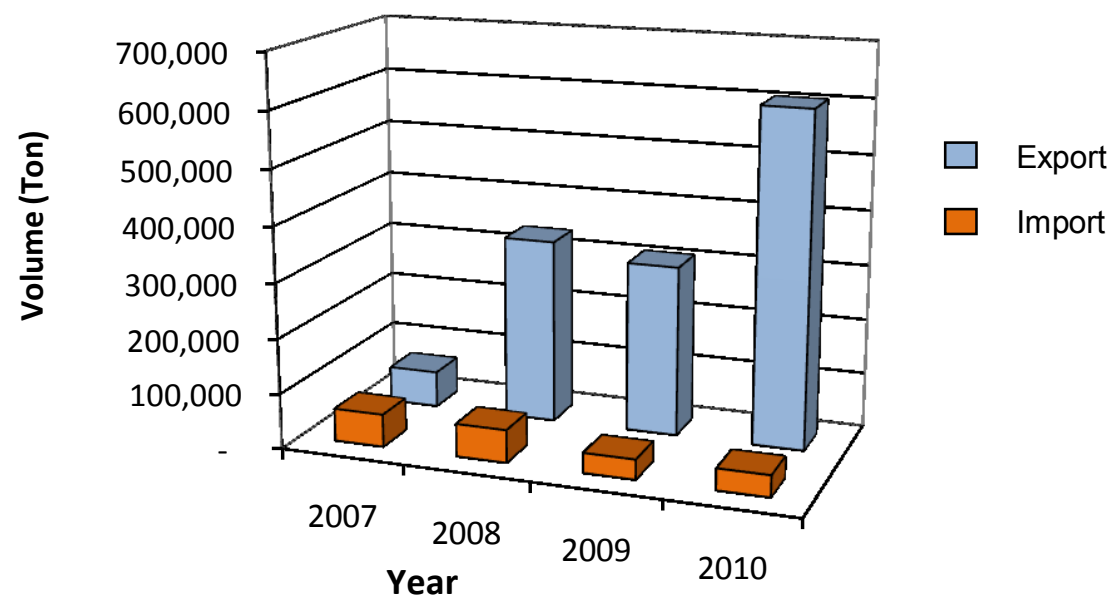

Source : Ministry of Industry, 2011

Figure 9. The Development of Export and Import of Indonesian Biodiesel in 2007-2010

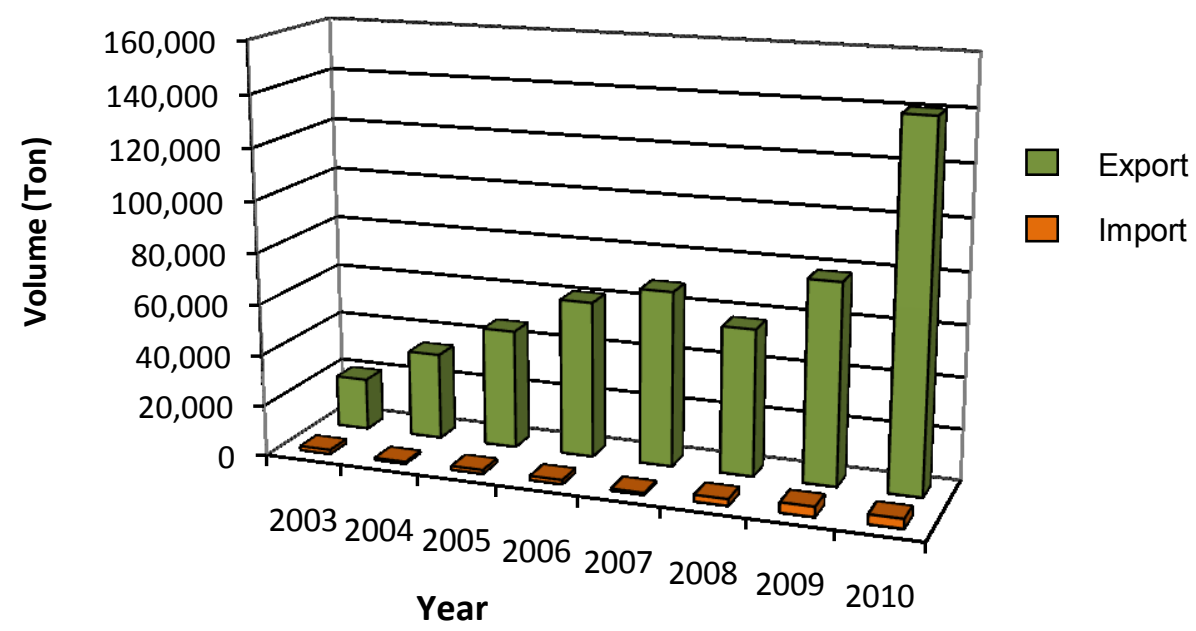

Source : Ministry of Industry, 2011

Figure 10. Graph of the Development of Export and Import of Indonesian Glycerin in 2003-2010

\subsection{Consumption Development of Palm Oil Derivatives}

In the last decade, the development of palm cooking oil industry was found to occur in line with the shift of public consumption pattern from coconut cooking oil to palm cooking oil. Indonesian Association of Plant Oil Industry (GIMNI), with the assumption of 240 million populations, reported a total domestic consumption of cooking oil of 3.24 million tons in 2010 with the average consumption of $13.5 \mathrm{~kg} / \mathrm{capita} / \mathrm{year}$. This consumption was estimated to slightly increase to $13.6 \mathrm{~kg} /$ year in 2011 making up the total domestic consumption of cooking oil of 3.26 million tons. This might be caused by lower buying power of Indonesian people.

Cooking oil consumption in USA and Europe was about $55 \mathrm{~kg} / \mathrm{capita} /$ year and in China and India was $20 \mathrm{~kg} / \mathrm{capita} /$ year. If cooking oil consumption is $20 \mathrm{~kg} /$ capita/year, the total domestic cooking oil consumption 
can reach 4.8 million tons. As cooking oil is a normal consumer good, this figure will be easily obtained if there is an increase in people average income.

Consumers of oleochemicals in form of fatty acid are producers of soap and detergent, intermediates, plastic, rubber, paper, lubricant, coating, personal care products, food and feed, candles, etc. with their shares as can be seen in Fig. 11.

Fatty alcohol markets include producers of soap and detergent, personal care products, lubricant, amines, etc. with their shares as can be seen in Fig. 12. More than two-third or about $80 \%$ of fatty acid was used as feedstock for surfactant production. As the processing industry of fatty alcohol into surfactant in Indonesia is still limited, most fatty alcohol produced in this country is exported to the global market.

Market opportunity for biodiesel is domestic consumption and export. Domestic consumption is estimated to keep increasing after the issuance of the Regulation of Ministry of Energy and Mineral Resources Number 32 Year 2008. According to this regulation, the utilization of plant oil by $20 \%$ for biodiesel, $15 \%$ for bioethanol, and $10 \%$ for PPO is mandatory in 2025. This regulation is valid for the utilization of biodiesel in transportation as part of Public Service Obligation (PSO), non PSO transportation, industry, commercial, and power plant. This regulation stipulates a mandatory use of other type of fuel in a gradual and sustainable way by commercial bodies which hold a business license and are direct users of fuel by utilizing and prioritizing locally produced biofuel.

Based on the mandatory use of biodiesel, in 2010, biodiesel production was 460,180 kiloliters used to fulfill the need of transportation sector $(236,502 \mathrm{kl})$, non transportation sector $(88,650 \mathrm{kl})$, industrial and commercial sectors $(48,495 \mathrm{kl})$, power plant sector $(86,533 \mathrm{kl})$. It is estimated that the use of biodiesel is increasing and reaches $6,866,983 \mathrm{kl}$ in 2025 .

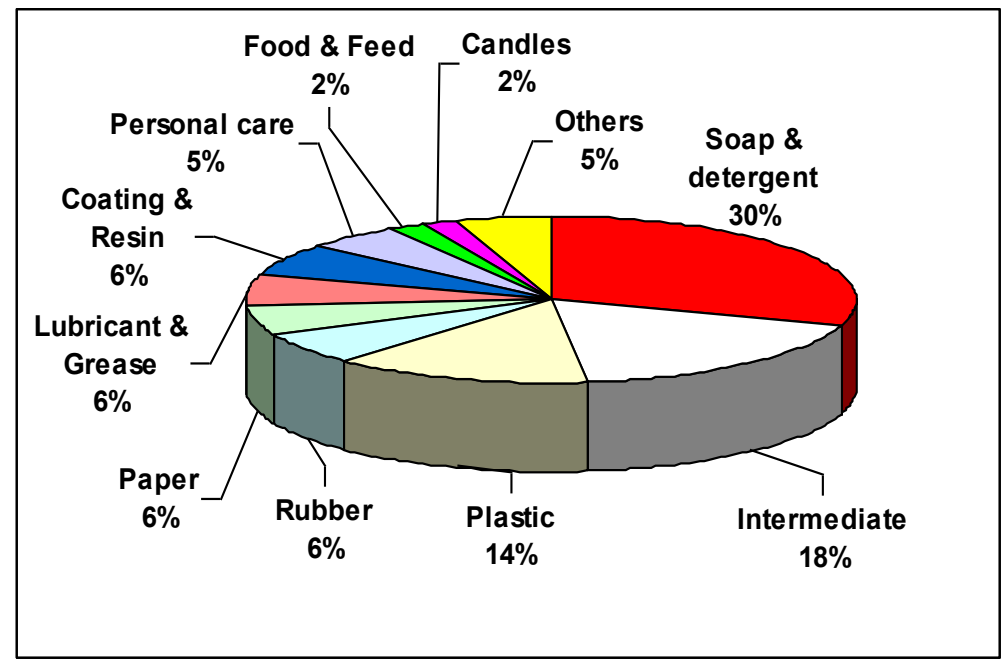

Figure 11. Market of oleochemicals in forms of fatty acid products

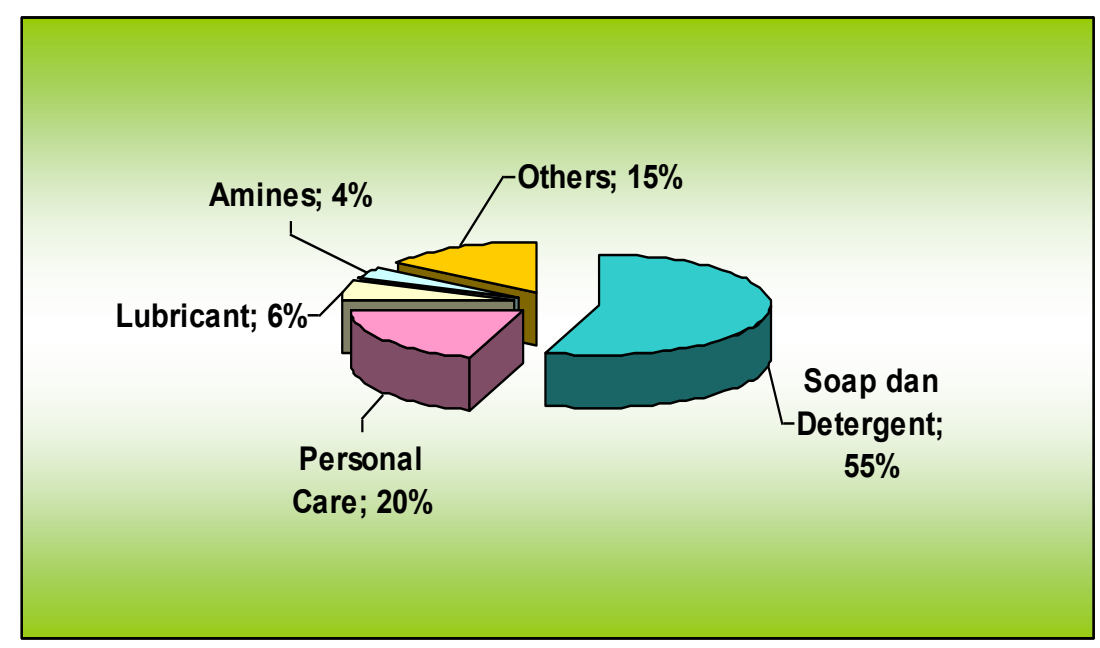

Figure 12. Market of oleochemicals in forms of fatty alcohol 
To support the development of biodiesel industry and the improvement of real capacity of Indonesian biodiesel industry, the government issued the Presidential Regulation Number 45 Year 2009 on the Supply and Distribution of Certain Fuel as a revision of Presidential Regulation Number 71 Year 2005. In this latest regulation, it is stipulated that biodiesel industries receive a subsidy which in 2010 was determined to be about Rp1,500-Rp2,000 per liter. This subsidy was expected to support Indonesian biodiesel industries based on their production capacity in order to meet domestic and export demands.

Glycerin consumers include producers of soap/cosmetics/pharmacy, alkyd resin, food, polyurethane, explosives, etc. with their shares as can be seen in Fig. 13.

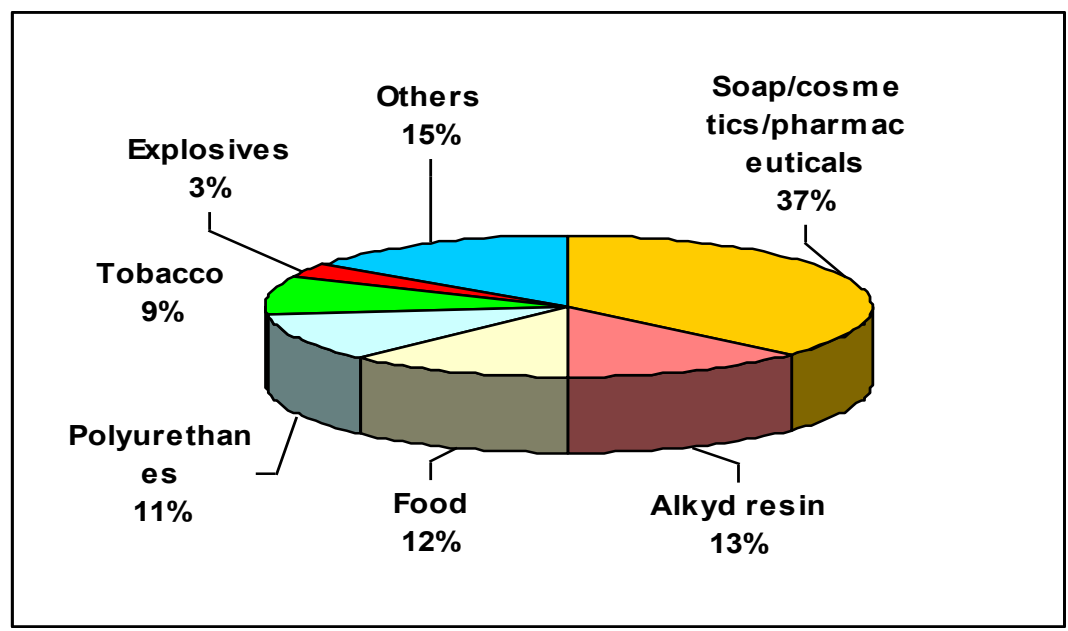

Figure 13. Market of oleochemicals in forms of glycerin

\subsection{The Development of Global Prices of Palm Oil Derivative Products}

Olein prices develops following the development of CPO prices. In 2009, on average, CPO prices decreased and this decrease was followed by the decrease in olein prices. The development of olein prices in 2006 to April 2011 is depicted in Fig. 14. Projected prices of olein is depicted in Fig. 15.

Compared to the development of prices of upstream products (CPO, PKO), the price of the derivative products (fatty acid) was relatively stable. However, in the last two years, the prices of fatty acid tended to follow the development of CPO and PKO prices. An increase and decrease in input prices was followed by an increase and decrease in output prices. This condition indicates that the market of oleochemical products is still open. Yet, the nominal increase in CPO and PKO prices is usually higher than that in oleochemical prices while the nominal decreases in prices of the two kinds of products are usually the same. In addition, there was a lag of time of output price changes in response to changes in prices of feedstock.

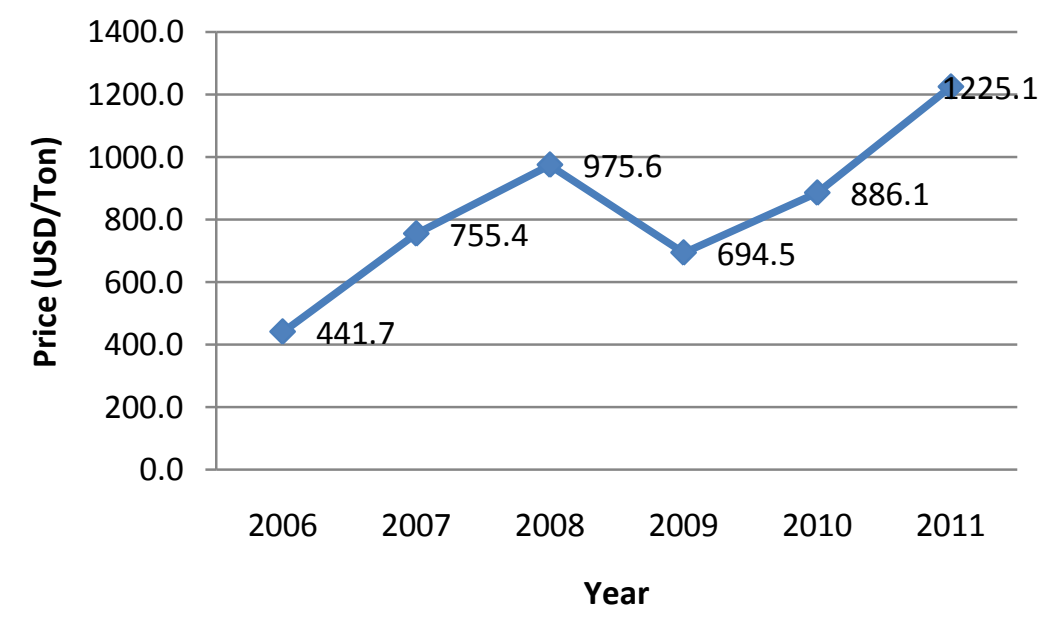

Source : MPOB, 2011

Figure 14. Graph of the World Price Development of Olein in 2006 - 2011 


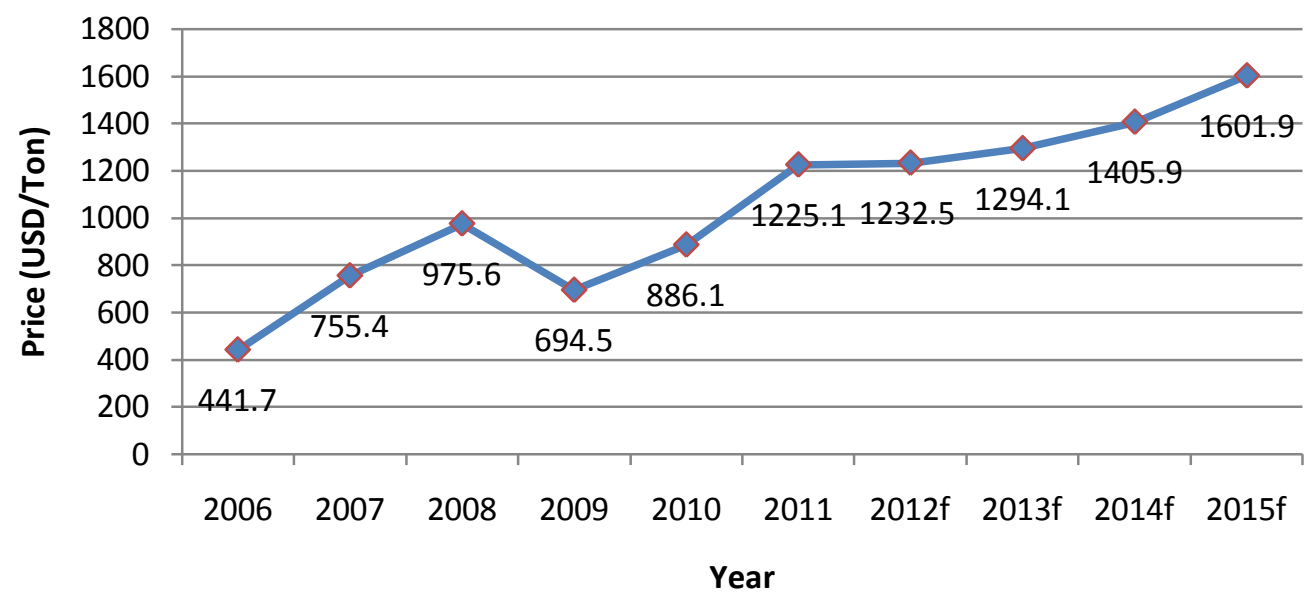

Source : MPOB, 2011 (processed data)

Figure 15. Graph of projected development of world price of olein in $2006-2015$

In Fig. 16, the development of global prices of fatty acid is depicted. Fig. 17 depicts the comparison of CPO and fatty acid prices development and Fig. 18 depicts the projected development of the global fatty acid prices.

In the last two years, prices of fatty alcohol tended to follow the development of $\mathrm{CPO}$ and PKO prices. This is indicated by the fact that a decrease in CPO and PKO prices in 2009 was followed by a decrease in fatty alcohol prices. In 2010, CPO and PKO prices increased which was also followed by an increase in fatty alcohol prices. Relatively similar to the behavior of fatty acid prices, the nominal increase in $\mathrm{CPO}$ and PKO prices was higher than that in oleochemical prices while the nominal decreases in prices of the two kinds of products were the same. In addition, there was a lag of time of output price changes in response to changes in prices of feedstock.

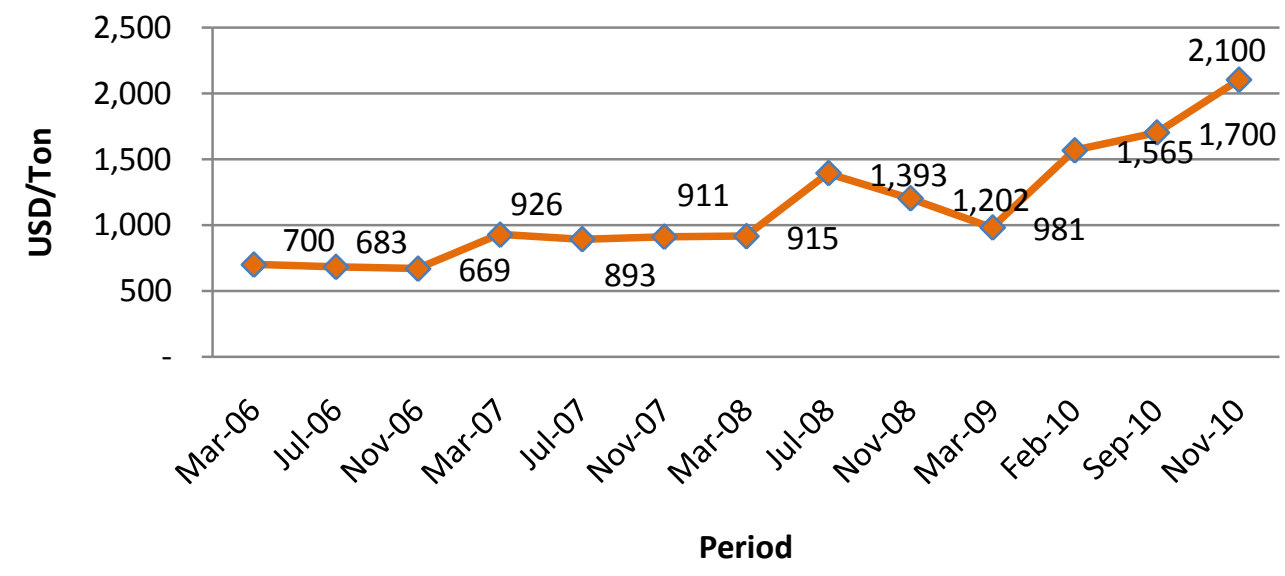

Source : ICIS, 2011

Figure 16. Graph of development of world price of fatty acid 


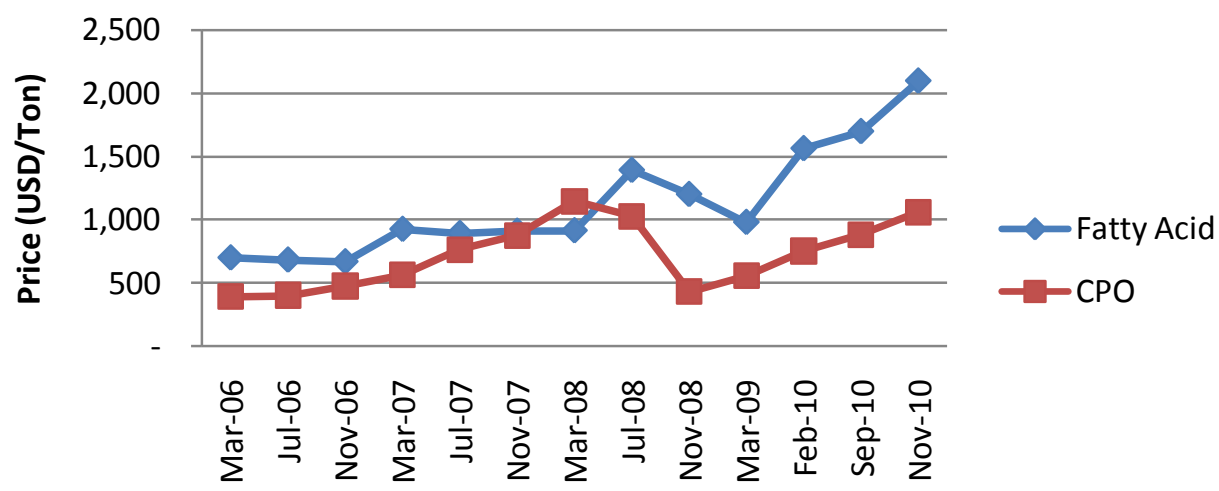

Source : ICIS, 2011 and www.indexmundi.com/

Figure 17. Graph of the comparison of the world prices of $\mathrm{CPO}$ and fatty acid

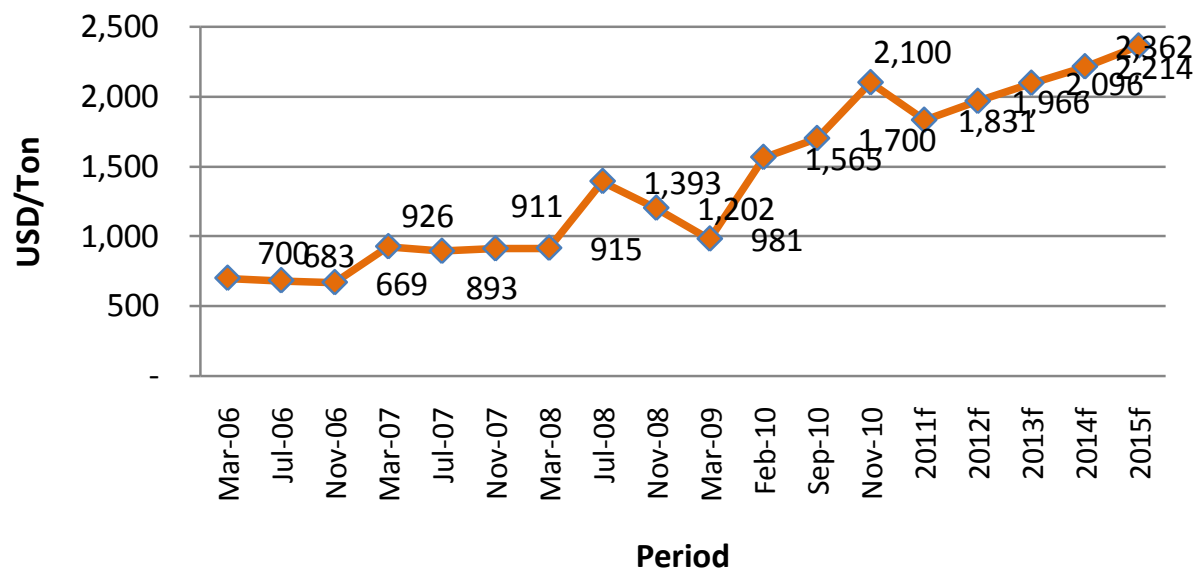

Source : ICIS, 2011 (processed data)

Figure 18. Graph of projected world price development of fatty acid

In Fig. 19, the development of the global prices of fatty acid is depicted. Fig. 20 depicts the comparison of global PKO and fatty alcohol prices development and Fig. 21 depicts the projected development of the global fatty alcohol prices.

In the last two years, there was a tendency that PME prices followed the changes in CPO prices. PME prices were below those of biodiesel made of soybean/soybean methyl ester (SME) found a lot in the USA and biodiesel made of rapeseed/rapeseed methyl ester (RME) found a lot in European countries. Based on the prices and feedstock, it was seen that in the global market, Indonesian biodiesel was considerably competitive. The projected development of biodiesel prices is depicted in Fig. 22.

Almost similar to those of other oleochemical products, in the last two years, prices of glycerin followed the changes in CPO prices. The development of glycerin prices is depicted in Fig. 23. The projected development of global glycerin prices is depicted in Fig. 24. 


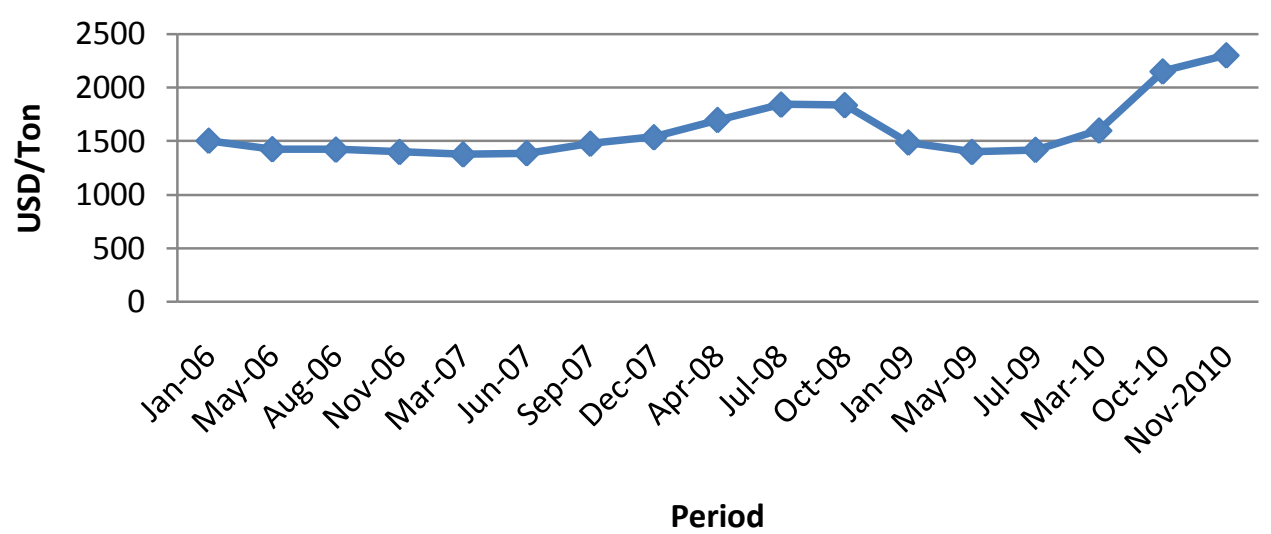

Source : ICIS, 2011

Figure 19. Graph of the development of world price of fatty alcohol

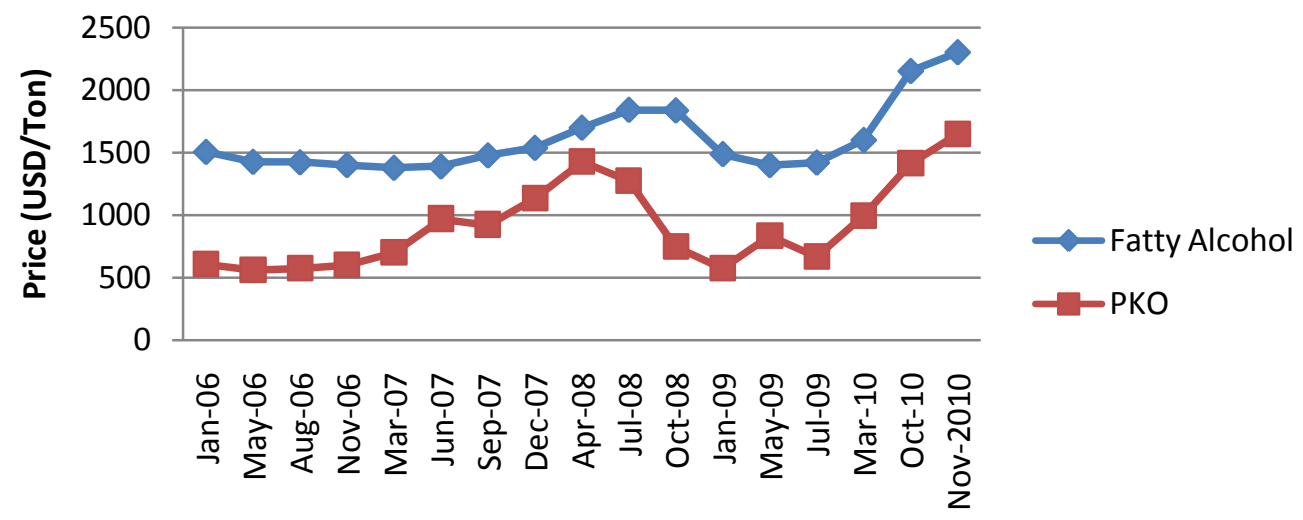

Source : ICIS, 2011 and www.indexmundi.com

Figure 20. Graph of the development of world prices of PKO and fatty alcohol

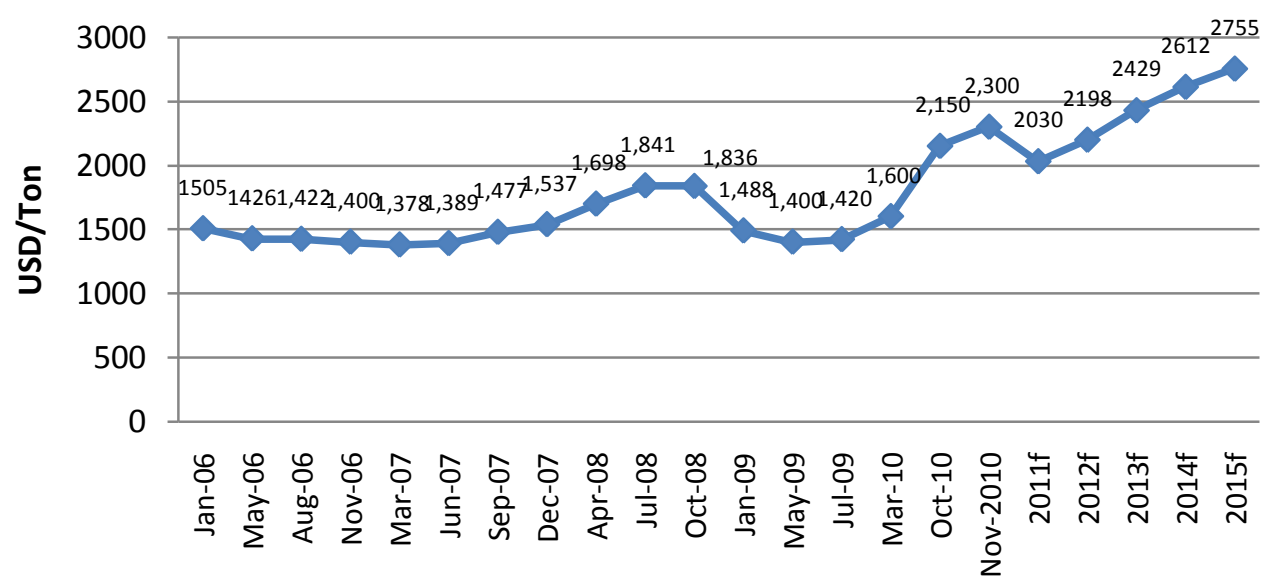

Period

Source : ICIS, 2011 (processed data)

Figure 21. Graph of projected development of world price of fatty alcohol 


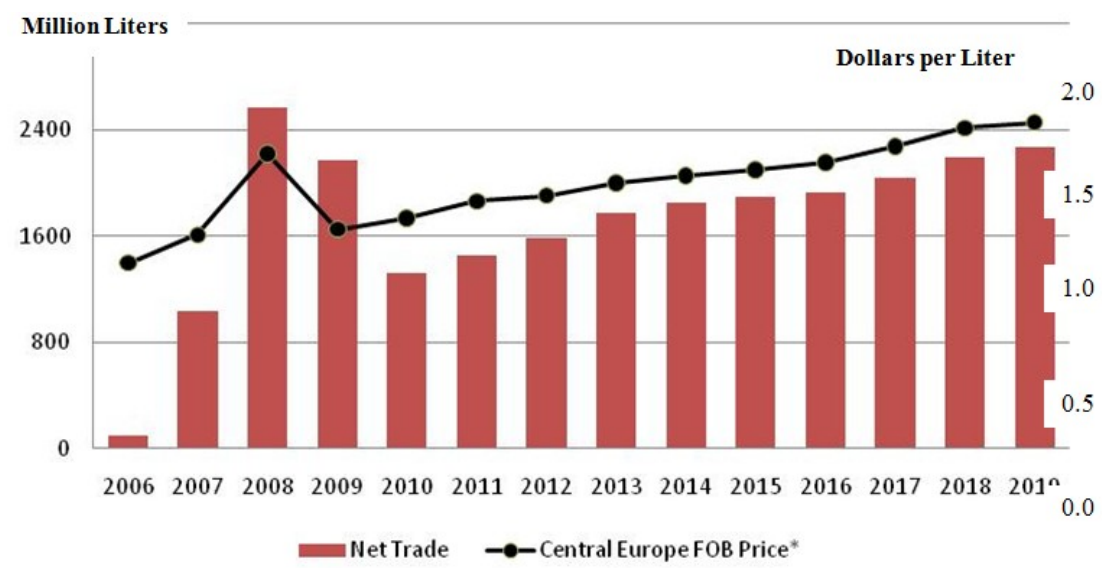

Source : http://www.thebioenergysite.com/articles/599/2010-us-and-world-agricultural-outlook (processed data)

Figure 22. The development trend of world price of biodiesel

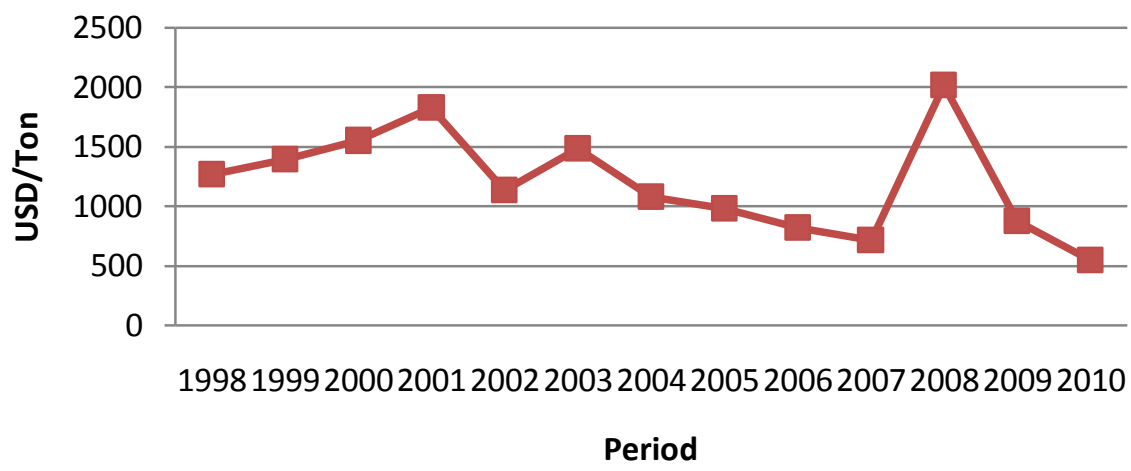

Source : ICIS, 2011

Figure 23. Graph of the development of world price of glycerin

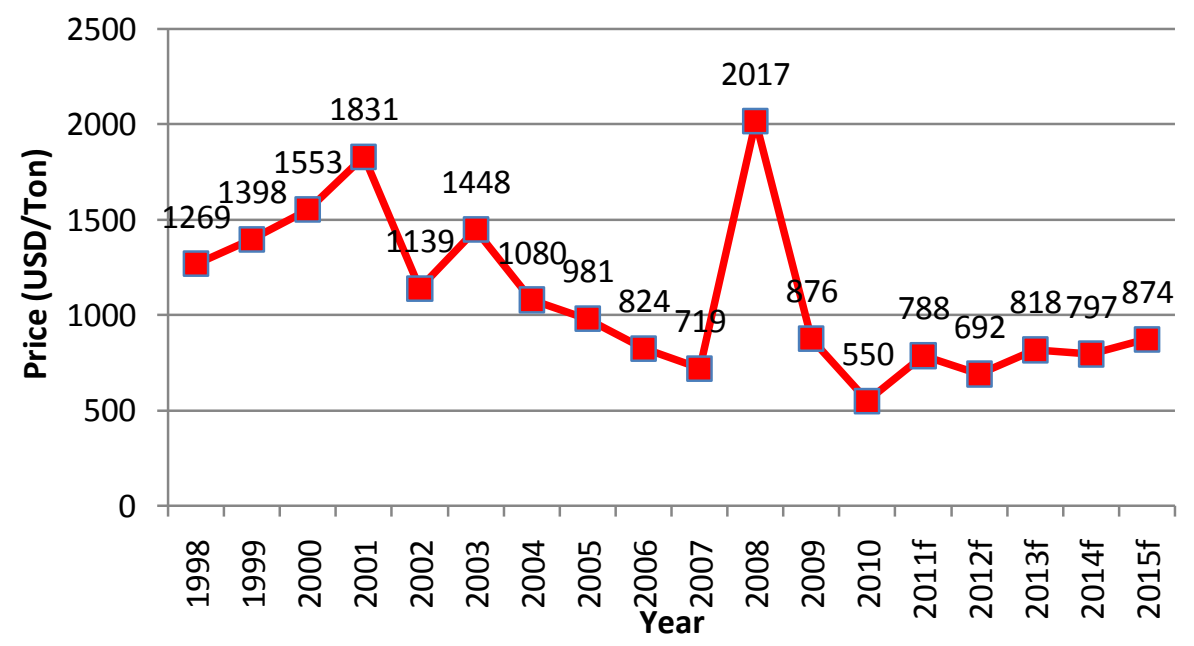

Source : ICIS, 2011(processed data)

Figure 24. Graph of the projected development of world price glycerin

\subsection{Policies of Indonesian Palm Oil}

In 2011, Indonesian government issued a Master plan Program for Acceleration and Expansion of Indonesia's Economic Development (MP3EI) with a vision of creating an independent, advanced, just, and prosperous Indonesian society and three missions as its main focus, namely (1) improvement of added value and value chain of production process and distribution and asset and access (potential) management of natural 
resources, areal geography, and human resources through the creation of economic activities which are integrated and synergized in/inter economic growth center regions, (2) supporting the realization of improved efficiency in production and marketing and integrated domestic markets in order to strengthen the competitiveness and resistance of national economy, (3) supporting the strengthening of innovation system in production, process, and marketing sides in order to strengthen the sustainable global competitiveness leading to an economy in innovation market. As a nationally superior commodity, palm oil is included in MP3EI program. The utilization of CPO in upstream industries in Indonesia is relatively low, about $27.41 \%$ of the total national $\mathrm{CPO}$ production. In order to improve the value of Indonesian palm oil in the export market through the development of palm oil derivative industry in Indonesia, since 2010, the government has developed a roadmap of the development of palm oil derivative/downstream industry in Indonesia. Based on this roadmap, the middle-term targets are to expand industrial clusters of palm oil derivatives in Sumatra and Riau and to create a conducive business and investment climate in palm oil sector. The long-term targets include the expansion of final product development, the creation of center of excellence for oleochemical industry, market control, the consolidation of environmentally friendly industry, and the integration of oil palm industry in East Kalimantan, Central Kalimantan, West Kalimantan, and Papua. In order to reach these middle-term targets, main actions to be done include developing cooperation among $\mathrm{CPO}$ and $\mathrm{CPO}$ derivative industries and supporting/related industries, integrating $\mathrm{CPO}$ and $\mathrm{CPO}$ derivative industries, developing $\mathrm{CPO}$ derivative industries into surfactant, lubricant, and biodiesel industries, developing R\&D cooperation with research institutions, higher education institutions, and industry, improving quality of products to comply with SNI standards, developing tool industries, developing supporting material industries, improving human resources quality, supporting financial institutions in providing credit and capital services, supporting marketing-related institutions, promoting investment, developing infrastructures, improving coordination and synergy with related institutions in policy making, making incentive policies to support industry development, eliminating regional regulations inhibiting the development of industry and forming an authority body for investment development.

In order for Indonesian palm oil be able to compete with Malaysian's, the government issued Ministry of Finance Regulation Number 75/PMK/011/2012 on the stimulation of export duty tax on palm oil and its derivative products which came into effect since 16 May 2012 based on the formulation of reference prices. Based on this regulation, the export duty tariff of raw palm oil and its derivative products was changed. If the price of palm oil is under USD750/ton, raw palm oil and its derivative products will be subjected to an export duty tariff of $0 \%$. A progressive export duty tariff is set out for every price increase of USD50 per ton and lower export duty tariff is set out for palm oil derivative products than that for raw palm oil.

\section{Conclusion And Recommendations}

Indonesian palm oil industry is developing. However, the development only occurs in its upstream industry. The development of palm oil derivative industry occurs so slowly that Indonesia's palm oil export is still dominated by CPO. This condition is in contrast with that in Malaysia whose palm oil export is dominated by the downstream products.

Therefore, in order to improve Indonesia's export of palm oil and its derivative products and to avoid excess supply, palm oil derivative industry should be developed. This is to improve the added value of oil palm for the most benefit of Indonesian people. With limited domestic palm oil consumption, the government needs to make policies that stimulate the improvement of export by stipulating more flexible export duty tariff and lower export duty tariff for oil palm derivative products that that for CPO. It also recommended that the government provide more budgets for promoting Indonesia's oil palm products overseas by forming a special institution filled in with oil palm experts.

\section{References}

[1]. Embassy of Indonesia in Singapura. 2013. Market Brief: Market Opportunity of Indonesian Palm Oil and Its Derivatives Product in Singapura. Singapura.

[2]. Statistic Bureau of Indonesia. 2013. Indonesian Statistic in 2013. Statistic Bureau of Indonesia, Jakarta

[3]. Statistic Bureau of Indonesia. 2013. Indonesia Foreign Trade Statistic in 2013. Statistic Bureau of Indonesia, Jakarta

[4]. Hambali, E., et.al. 2010. Feasibility Study and Basic Design of Establishment of Integrated Biodiesel Industry with Surfactant, Beta Carotene, Tocopherol dan Tocotrienol Industry. SBRC-IPB. Bogor

[5]. ITPC Lyon. 2012. Market Brief about HS Code 1511 "Palm oil" in French. Lyon.

[6]. Ministry of Industry Republic of Indonesia. 2010. Industries Performance of Indonesian Palm Oil and Its Downstream industries. Jakarta.

[7]. $\quad$ MPOC. 2012. Malaysian Palm Oil Council Annual Report 2011.

[8]. Purwanto, S.K. 2002. Impact of Domestic Policies and External Factors on International Trade of Vegetable Oil. Thesis. Bogor Agricultural University. Bogor

[9]. SBRC. 2011. Analysis and Prospects of Indonesian Palm Oil Downstream Industry. Surfactant and Bioenergy Research Centre. Bogor. 